\title{
Chemical composition and larvicidal activity of Moroccan Atlas Cedar (Cedrus atlantica Manetti) against Culex pipiens (Diptera: Culicidae)
}

\author{
Yassine EZ ZOUBI ${ }^{1,2}$, Fouad EL-AKHAL ${ }^{2}$, Abdellah FARAH ${ }^{2}$, Khalid TAGHZOUTI $^{3}$, Abdelhakim EL OUALI LALAMI ${ }^{1,4^{*}}$ \\ ${ }^{1}$ Regional Diagnostic Laboratory of Epidemiological and Environmental Health, Regional Health Directorate, El Ghassani Hospital, Fez 30000 , Morocco. \\ ${ }^{2}$ Laboratory of Applied Organic Chemistry, faculty of sciences and technology, Sidi Mohamed Ben Abdellah University, po.box 2202 - route d'Imouzzer, \\ Fez, Morocco. ${ }^{3}$ Laboratory of Animal Physiology, Department of Biology, Faculty of Science, University Mohammed V, Rabat, Morocco. \\ ${ }^{4}$ Institute of Nursing Professions and Health Techniques of Fez (annex Meknes), Regional Health Directorate, El Ghassani Hospital, Fez 30000 , Morocco.
}

\begin{tabular}{|c|c|}
\hline ARTICLE INFO & ABSTRACT \\
\hline Article history: & \multirow{10}{*}{$\begin{array}{l}\text { The aim of this research was to determine the larvicidal activity of essential oil of Cedrus atlantica Manetti from } \\
\text { Moroccan Middle Atlas against Culex pipiens, one of the most widely distributed mosquitoes in the world. The } \\
\text { essential oil was obtained from aerial part of plant by hydrodistillation. The biological test was performed using } \\
\text { a methodology inspired the WHO standard protocol. The percent yield of the essential oil of Cedrus atlantica } \\
\text { Manetti was } 1.12 \pm 0.2 \% \text {. The GC/MS analysis of essential oil from Cedrus atlantica Manetti revealed the } \\
\text { presence of twenty five ( } 25) \text { compounds, representing } 97.48 \% \text { of the total composition. The major group of } \\
\text { compounds, the main one being } \alpha \text {-himachalene }(35.34 \%) \text { followed by } \beta \text {-himachalene }(13.62 \%), \gamma \text {-himachalene } \\
(12.6 \%) \text {, cedrol ( } 10.32 \%) \text {, isocedranol }(5.52 \%) \text { and } \alpha \text {-pinene }(5.5 \%) \text {. The Lethal Concentrations LC } C_{50} \text { and LC } 90 \\
\text { measured for the Moroccan Cedrus atlantica Manetti essential oil appears to be effective with respective values } \\
\text { of } 782.43 \text { ppm and } 1253.93 \mathrm{ppm} \text { and the minimum levels necessary to achieve } 100 \% \text { larval mortality of Culex } \\
\text { pipiens was valued at } 1500 \mathrm{ppm} \text {. The larvicidal activity of essential oil of Cedrus atlantica against Culex } \\
\text { pipiens, has not been studied previously in Morocco, may prove helpful in developing effective and ecofriendly } \\
\text { larvicides, as favorable alternatives for the management of mosquitoes. }\end{array}$} \\
\hline Received on: & \\
\hline Accepted on: 10/03/2017 & \\
\hline Available online: $30 / 07 / 2017$ & \\
\hline Key words: & \\
\hline Essential Oil, Chemical & \\
\hline Analysis, Larvicidal activity, & \\
\hline Cedrus atlantica Manetti, & \\
\hline Culex pipiens, Morocco. & \\
\hline & \\
\hline
\end{tabular}

\section{INTRODUCTION}

Culex pipiens (C. pipiens) (Diptera: Culicidae) is one of the most widely distributed mosquitoes in the world. The species commonly referred to as "house mosquito", can be found in urban and suburban areas and lives near people (Bernard et al., 2001). Several commercially available insecticides (e.g. temephos, chlorpyrifos-methyl, diflubenzuron) can be effective to control the species at immature stages (Cetin et al., 2006a, 2006b). However, many of these chemical insecticides are expensive and harmful to the environment as well as to humans

\footnotetext{
* Corresponding Author Abdelhakim El Ouali Lalami, Institute of Nursing Professions and Health Techniques of Fez (annex Meknes), Regional Health Directorate, El Ghassani Hospital,Fez, Morocco.Email: eloualilalami @ yahoo.fr
}

(Huseyin et al., 2009). The WHO expert committee (Samuel et al., 2013; WHO, 1982) felt the resistance in vectors was probably the "biggest single obstacle in the struggle against vector-borne diseases". Many mosquito species are known to have developed resistance to temephos in many parts of the world and also in Morocco (El-akhal et al., 2016; El Ouali Lalami et al., 2014; Cui et al., 2006; Braga et al., 2004; Faraj et al. 2002). Natural plant products can be an excellent alternative source of novel insecticidal chemistries. With some exceptions, botanicals are considered to be less toxic to non-target species and more environmentally friendly because of their biodegradable nature (El Ouali Lalami et al., 2016; Copping 1996). In Morocco, several studies have been carried out on the larvicidal effect of plants against Culex pipiens, for exemple Origanum majorana (El-Akhal et al., 2014), 
Lavandula stoechas (El Ouali Lalami et al., 2016), Citrus sinensis and Citrus aurantium (El-Akhal et al., 2014). Currently, the genus Cedrus includes three extant species native to the Mediterranean mountains (Cedrus atlantica Manetti from Algeria and Morocco; Cedrus libani Rich. in Asia Minor; Cedrus brevifolia Henry in Cyprus) and in the Himalaya (Cedrus deodara Don) (Farjon, 2008). The Atlas cedar is an endemic species of North Africa Mountains (Morocco, Algeria). In Morocco, the Atlas cedar occupies an area of 132,000 hectares divided into two blocks of unequal importance: the Rif; the Moroccan Middle and High Atlas (Cheddadi et al., 2009; M'hirit et al., 1993), presenting an altitudinal ranging from $1500 \mathrm{~m}$ to $2600 \mathrm{~m}$. The Middle Atlas in northern Morocco contains about the $80 \%$ of the world's Atlas cedar forest area (Linares et al., 2011; Benabid, 1994).

This raw material would be important for essential oil production to be used for its medicinal properties and perfumery (Boudarene et al., 2004). Indeed, essential oils are a part of several products such as drugs and perfumes (Adams, 1991). The essential oil of $C$. atlantica Manetti (C. atlantica) has been shown to possess antifungal (Bouchra et al., 2003), antimicrobial (Zrira and Ghanmi, 2016), antiviral (Monica et al., 2008), and antiinflammatory activities (Sugita et al., 2004), but its larvicidal activity is not reported against $C$. pipiens in the literature.

In this work, the chemical quality of the Atlas cedarwood oil obtained from the middle Atlas forest were studied and its insecticidal activity against larvae of $C$. pipiens was determined in the first time in Morocco.

\section{MATERIALS AND METHODS}

\section{Plant material and extraction of the Essential Oil (EO)}

The aerial parts (leaves, stems and wood) of C. atlantica (Fig. 1) are collected in Boulmane region (Middle Atlas Mountains, Morocco), between April and May 2014. The botanical identification and authenticated voucher specimens have been deposited in the Herbarium of National Institute of Medicinal and Aromatic Plants, Sidi Mohamed Ben Abdellah University, Fez, Morocco. Samples of $100 \mathrm{~g}$ of the fresh aerial parts of $C$. atlantica were subjected to hydrodistillation for 2 hours using a Clevenger apparatus; the obtained Essential Oil (EO) was stored at $4^{\circ} \mathrm{C}$ so that can be used in the upcoming experiments.

\section{Chemical characterization of essential oil of $C$. atlantica}

The chromatographic analysis of essential oil was conducted in "Centre Universitaire Régionale d'Interface" (CURI) in Fez city. The gas chromatography (GC) analysis were performed using a Hewlett-Packard (HP 6890) gas chromatograph (flame ionization detector, FID), equipped with a HP-5 capillary column $(30 \mathrm{~m} \times 0.25 \mathrm{~mm} \times 0.25 \mu \mathrm{m})$. The temperature was programmed from $50^{\circ} \mathrm{C}$ after $5 \mathrm{~min}$ initial hold to $200^{\circ} \mathrm{C}$ at $4^{\circ} \mathrm{C}$ $\min ^{-1}$. GC conditions were as follows: $\mathrm{N}_{2}$ as carrier gass $(1.7 \mathrm{ml}$

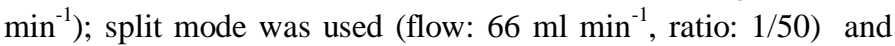
the injected volume was about $1 \mu$ l. The Gas Chromatography/Mass Spectrometry (GC/MS) analysis were performed by a Hewlett-Packard Gas Chromatographer (HP 6890) coupled with a mass spectrometer (HP 5973). Fragmentation was performed by electron impact at $70 \mathrm{eV}$. The carrier gas is helium whose flow is fixed at $1.5 \mathrm{ml} / \mathrm{min}$. The injection mode was split (split ratio: 1/70). The apparatus was controlled by a "Chemstation" computer system. The identification of the components is based on the comparison of their mass spectra (GC/MS), respective with spectra of the library (NIST 98), of the bibliography (Adams, 2007), Kovats index for each compound on OPTIMA-5 column was calculated in reference to n-alkanes.

\section{Characteristics of larval site}

The collection of larvae of $C$. pipiens was performed in a breeding site located in the urban area of the city of Fez, called (Grand Canal : $402 \mathrm{~m}$ altitude, $30^{\circ} 03^{\prime} 37^{\prime \prime} \mathrm{N}$ and $5^{\circ} 08^{\prime} 35^{\prime \prime} \mathrm{E}$ ). This site is characterized by a very high density of Culicidae larvae.

\section{Collecting larvae of $C$. pipiens}

Larvae were collected using a rectangular plastic tray in June 2014. The larvae gathered were maintained in breeding in rectangular trays at an average temperature of $21.7^{\circ} \mathrm{C} \pm 2^{\circ} \mathrm{C}$ in the Entomology Unit at the Regional Diagnostic Laboratory Epidemiological and Environmental Health (RDLEH) falling within Regional Health Directorate of Fez.

\section{Identification of larvae}

The identification of morphological characters of larvae has been determined using the Moroccan key of identification of Culicidae (Himmi et al., 1995) and the identification software of mosquitoes of the Mediterranean Africa (Brunhes et al., 2000).

\section{Protocol of larval susceptibility testing}

The susceptibility tests were carried out in accordance with the standard protocol developed by WHO in 2005 (WHO, 2005). From the initial essential oil ( $1 \mathrm{~mL}$ stock solution) of plant, concentrations of $250,500,750,1000,1250$ and $1500 \mathrm{ppm}$ were prepared. Preliminary experiments were used to select a range of concentrations for the tests previously mentioned. $1 \mathrm{~mL}$ of each solution prepared was placed in beakers containing $99 \mathrm{~mL}$ of distilled water in contact with 20 larvae of stages 3 and 4; the same number of larvae was placed in a beaker containing $99 \mathrm{~mL}$ of distilled water plus $1 \mathrm{~mL}$ of ethanol. Three replicates were carried out for each dilution and for the control. After 24 hours of contact, we counted the living and dead larvae. The results of susceptibility testing were expressed in the percentage of mortality versus the concentration of plant extract used. If the percentage of mortality in control is greater than 5\%, the percentage of mortality in larvae exposed to the essential oil shall be corrected by using Abbott's formula (Abbott, 1925):

$\%$ Mortality Corrected $=[(\%$ Mortality Observed $-\%$ Mortality Control) / (100 - \% Mortality Control) $) \times 100$.

If the control mortality exceeds $20 \%$, the test is invalid and must be repeated. 
Table 1: Percent yield and physical characters of C. atlantica from Morocco.

\begin{tabular}{ccccc}
\hline \multirow{2}{*}{ Botanical name } & \multirow{2}{*}{ Part used } & \multicolumn{3}{c}{ Physical characteristics } \\
\cline { 2 - 5 } & & Color & Odor & Density (g/ml) \\
\hline Cedrus atlantica Manetti & Areal part & Light Golden Yellow & dirty-woody, resinous, urinous odour & 0.948 \\
\hline
\end{tabular}

\section{Data processing}

For the data processing we used the log-probit analysis (Windl version 2.0) software developed by CIRAD-CA/MABIS (Giner et al., 1999). The analysis of the averages and standard deviation was also performed by using the test of analysis of variance ANOVA.

\section{RESULTS AND DISCUSSION}

\section{Percent yield and physical characters of $C$. atlantica}

The percent yield of the hydro-distilled volatile oil from aerial parts of $C$. atlantica and its physical characters are summarized in Table 1. The average yield of the cedar essential oil of Eastern Middle Atlas was $1.12 \pm 0.2 \%$. Our result is lower than that obtained for the origin of the High Atlas (Morocco) $(2.6 \%$ ) (Rhafouri et al., 2014) and also of that of Djurdjuran region in Algeria (1.7\%) (Boudarene et al., 2004). On the other hand our result is superior to that found by Mathieu et al. (2011) about $C$. atlantica growing in Corsica $(0.05-0.49 \%)$.

\section{Chemical composition of the essential oil}

The GC/MS analysis of essential oil extracted from $C$. atlantica revealed the presence of twenty five (25) compounds, representing $97.48 \%$ of the total composition (Table 2). The major group of compounds, the main one being $\alpha$-himachalene $(35.34 \%)$ followed by $\beta$-himachalene (13.62\%), $\gamma$-himachalene (12.6\%), cedrol $(10.32 \%)$, isocedranol $(5.52 \%)$ and $\alpha$-pinene $(5.5 \%)$. The chemical composition of our oil revealed that was relatively similar to those of other $C$. atlantica essential oils analyzed by Teisseire and plattier, (1974), which the major compounds was himachalene and it's relatively similar to the composition of essential oil of leaves of $C$. atlantica study in Lebanon, which the major constituents were himachalol (22.50\%), $\beta$-himachalene $(21.90 \%)$ and $\alpha$-himachalene $(10.50 \%)$ (Monica et al., 2008). Contrary to the composition of essential oils of leaves of $C$. atlantica study in Algeria, which main constituents were: $\alpha$-pinene (37.1-5.5\%), $\beta$-pinene (8.6-1.9\%), myrcene (3.6-0.6\%), limonene (2.5-0.6\%), bornyl acetate $(5.4-4.0 \%)$, (E)- $\beta$-farnesene $(6.8-1.9 \%)$ and manool (8.3-20.7\%) (Boudarene et al., 2004). In Morocco, a recent study realized by Zrira and Ghanmi (2016), about essential oil of $C$. atlantica from Azrou Province ( $89 \mathrm{~km}$ south of Fez city), found that the main compounds identified are as follows: $\alpha-(\mathrm{E})-$ atlantone (19.3\%), $\beta$-himachalene (15.1\%), 8-cedren-13-ol, (13.1 $\%), \alpha$-himachalene $(5.1 \%)$, cedroxyde $(4.6 \%)$ and deodarone (4.6 $\%)$. The wingless seeds essential oil of $C$. atlantica from Morocco (Regional Station of Azrou City Forest), isolated by Rachid et al. (2014), was characterized by high contents of the monoterpene hydrocarbons such as $\alpha$-pinene (46.16\%), manool (25.47\%), bornyl acetate $(10.18 \%), \beta$-pinene $(5.95 \%)$ and $\alpha$-terpinene $(2.71 \%)$. In our study, there was an absence of some major constituents like himachalol, $\alpha$-(E)-atlantone, deodarone and $\beta$-pinene, previously reported by Zrira and Ghanmi (2016), Monica et al. (2008) and Aberchane et al. (2003). This observed difference qualitative and quantitative between the chemical composition of the $C$. atlantica essential oils, could be explained by climatic conditions, the specific geographical factors to each region (Mansouri et al., 2010), genetics (degree of hybridization), part of plant extract and harvest period (Muñoz et al., 2007; Marcum et al., 2006).

Table 2: Chemical composition of areal part of essential oil of $C$. atlantica from Morocco.

\begin{tabular}{|c|c|c|c|}
\hline Peak & $\mathbf{K I}$ & Compounds & $\%$ Area \\
\hline 1 & 924 & $\alpha$-thujene & $t r^{*}$ \\
\hline 2 & 930 & $\alpha$-pinene & 5.5 \\
\hline 3 & 969 & sabinene & 0.13 \\
\hline 4 & 1127 & Rose oxide & 0.25 \\
\hline 5 & 1447 & $\alpha$-himachalene & 35.34 \\
\hline 6 & 1476 & $\gamma$-himachalene & 12.6 \\
\hline 7 & 1480 & $\gamma$-curcumene & 1.1 \\
\hline 8 & 1499 & $\beta$-himachalene & 13.62 \\
\hline 9 & 1526 & $\beta$-sesquiphellandrene & 0.72 \\
\hline 10 & 1542 & $\alpha$-calacorene & 0.1 \\
\hline 11 & 1573 & oxydohimachalene & 0.9 \\
\hline 12 & 1591 & Caryophyllene oxide & 0.1 \\
\hline 13 & 1594 & longiborneol & 1.18 \\
\hline 14 & 1611 & cedrol & 10.32 \\
\hline 15 & 1620 & cedranone & 1.62 \\
\hline 16 & 1628 & 1-epi-cubenol & 0.71 \\
\hline 17 & 1661 & isocedranol & 5.52 \\
\hline 18 & 1669 & 5-isocedrol & 1.47 \\
\hline 19 & 1693 & Z-trans bergamotol & 0.12 \\
\hline 20 & 1694 & deodarone & 0.1 \\
\hline 21 & 1704 & cedroxyde & 1.95 \\
\hline 22 & 1717 & Z- $\alpha$-atlantone & 1.3 \\
\hline 23 & 1736 & khusimol & 1.08 \\
\hline 24 & 1773 & E- $\alpha$-atlantone & 1.65 \\
\hline 25 & 1775 & 14-hydroxy-muurolene & 0.1 \\
\hline \multicolumn{3}{|c|}{ Total identified constituents } & $97.48 \%$ \\
\hline
\end{tabular}

*tr: Trace for percentages $\leq 0.07 \%$. KI: Kovats Index determined on OPTIMA5 non-polar column in reference to n-alkanes.

\section{Variation in mortality rate and Lethal Concentrations $\left(\mathbf{L C}_{\mathbf{5 0}}\right.$ and $\mathrm{LC}_{90}$ )}

After exposing the larvae $C$. pipiens to different concentrations of EO of $C$. atlantica for $24 \mathrm{~h}$, the percentage of mortality varied according to concentrations (Figure 2). The minimum concentration of $C$. atlantica EO required achieving $100 \%$ of $C$. pipiens larvae mortality was 1500 ppm. Figure 1 also shows the different concentrations used with their standard deviations and their larvicidal activity, we have found that the mortality rate varies according to the concentrations (Figure 2) and the larval mortality rate reached $100 \%$ at a concentration of 1500 ppm 


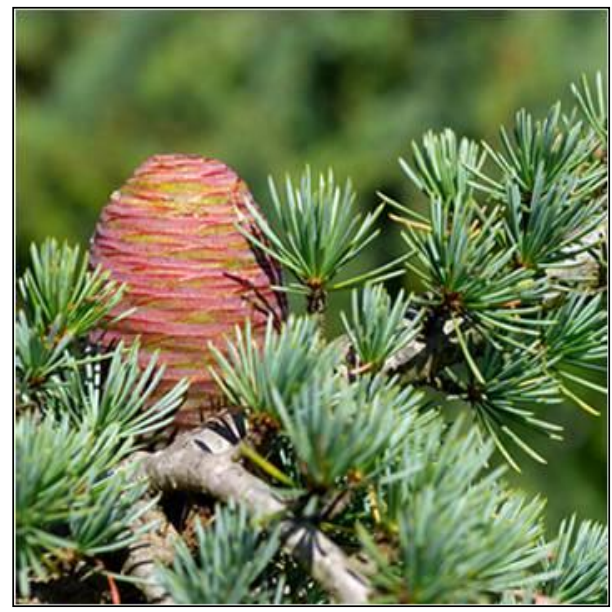

Fig. 1: Cedrus atlantica Manetti of Morocco.

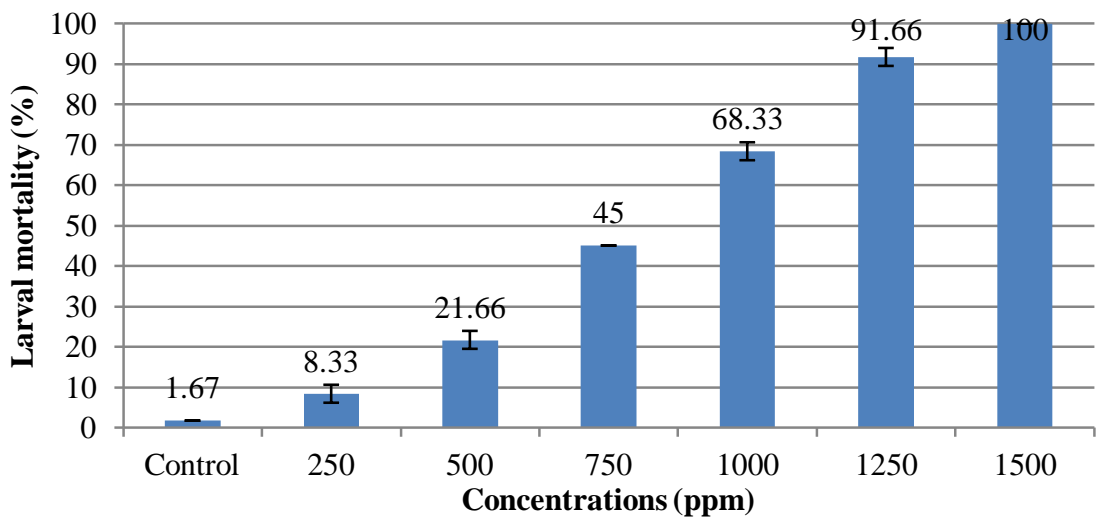

Fig. 2: Percentage of mortality recorded in the test sensitivity by essential oil of $C$. atlantica on C. pipiens.

Table 3: Lethal concentrations $\mathrm{LC}_{50}$ and $\mathrm{LC}_{90}$ of larvae of $C$. pipiens after 24h.

\begin{tabular}{|c|c|c|c|c|}
\hline Plant & LC $_{50}(\mathrm{ppm})(\mathrm{LI}-\mathrm{UI})^{*}$ & LC $_{90}(\mathrm{ppm})(\mathrm{LI}-\mathrm{UI})^{*}$ & Equation of the regression line & Calculated $C h i$-square $\left(\chi^{2}\right)$ \\
\hline C. atlantica & 782.43 (554.77-934.84) & $1253.93(1042.80-1900.82)$ & $Y=-18.10651+6.25776 * X$ & 11.063 \\
\hline
\end{tabular}

*Ll-Ul: Lower Limit-Upper Limit.

Table 3 demonstrates that C. pipiens EO remains effective while using concentrations of $782.43 \mathrm{ppm}$ for $\mathrm{LC}_{50}$ (which varies between a lower limit $554.77 \mathrm{ppm}$ and an upper limit of $934.84 \mathrm{ppm}$ ) and $1253.93 \mathrm{ppm}$ for $\mathrm{LC}_{90}$ (which also varies between a minimum of $1042.8 \mathrm{ppm}$ and a maximum value of $1900.82 \mathrm{ppm})$. Table 3 shows also the regression equation and the Chi-square $(\chi 2)$ analyses results. The regression analysis indicates that the mortality rate is positively correlated with $C$. pipiens concentration.

Taking into account the absence of studies on $C$. atlantica essential oil against $C$. pipiens, we tried to compare the action of Cedrus family against the $C$. pipiens. A study realized by Huseyin et al. (2009) demonstrated that the larvicidal activity of Cedrus libani from Antalya (southwestern Turkey) on C. pipiens essential oil, with $\mathrm{LC}_{50}$ values ranging from 47.8 to $116.0 \mathrm{ppm}$. The larvicidal activity observed in the essential oil of $C$. atlantica against $C$. pipiens could be explained by the chemical composition of this oil and the action or effect of compound majority. Indeed, Naples et al. (1992) reported that cedrol, in particular, a principal component of cedar wood oil, seems to have a high toxicity to cercariae (Schistosoma mansoni), a parasite for humans. Himachalenes and atlantones fractions essential oil of Himalayan cedar (C. deodara) showed insecticidal activity against Plutella xylostella (Chaudhary et al., 2011).

\section{CONCLUSION}

The essential oil obtained from cedar wood had a wide variety of volatile constituents, which made up $97.48 \%$ of the total essential oil. The essential oil yield was $1.12 \pm 0.2 \%$ and the major constituents were $\alpha$-himachalene (35.34\%), $\beta$-himachalene (13.62\%), $\gamma$-himachalene (12.6\%), cedrol (10.32\%), isocedranol (5.52\%) and $\alpha$-pinene (5.5\%). The oil also showed, an interesting larvicidal activity against $C$. pipiens with values in the order of $\mathrm{LC}_{50}=782.43 \mathrm{ppm}$ and $\mathrm{LC}_{90}=1253.93 \mathrm{ppm}$.

Our results suggest that essential oil of $C$. atlantica has potential to be used in the search for chemical components as new larvicides. Further studies are needed to determine and isolate major oil components that are most effective for larvicidal activity.

Conflict of Interests: There are no conflicts of interest.

Acknowledgements: This work did not receive a funding.

\section{REFERENCES}

Aberchane M, Satrani B, Fechtal M and Chaouch A. Infection effect of cedar Atlas wood by Trametes pini and Ungulina officinalis on chemical composition and antibacterial and antifungal activities of essential oils. Acta Bot Gallica, 2003; 150 (2):223-229.

Adams RP. Cedar wood oil- Analyses and Properties. In: Modern methods of plant analysis oils and waxes. Edits., H.F. Linskens and J.F. Jackson, 1991:159-173, Springer-Verlag. Publ.

Adams RP. Identification of Essential Oil Components by Gas Chromatography/Mass Spectrometry, 4th Edition. Allured Publishing Corporation, 2007:1-804.

Benabid A. Biogéographie phytosociologie et phytodynamique des cédraies de l'Atlas (C. atlantica, Manetti). Le cèdre de l'Atlas. Actes du séminaire international sur le cèdre de l'Atlas. Ann Rech For Maroc, 1994; 27:62-76.

Bernard KA, Maffei JG, Jones SA, Kauffman EB, Ebel GD, Dupuis AP, Ngo KA, Nicholas DC, et al. NY State West Nile Virus Surveillance 
Team. West Nile virus infection in birds and mosquitoes, New York State. Emerg Infect Dis, 20017:679-685.

Bouchra C, Mohamed A, Mina IH, Hmamouchi M.. Antifungal activity of essential oils from several medicinal plants against four postharvest citrus pathogens. Phytopathol Mediterr, 2003; 42(3):251-256.

Boudarene L, Baaliouamer A, Meklati BY and Scharff C.. Composition of the Seed Oils from Algerian C. atlantica G. Manetti. J Essent Oil Res, 2004; 16:61-63.

Braga IA, Silva S, Valle D. Aedes aegypti resistance to temephos during 2001 in several municipalities in the States of Rio de Janeiro, Sergipe and Alagoas, Brazil. Mem I Oswaldo Cruz, 2004; 99: 199-203.

Cetin H, Yanikoglu A, Kocak O, Cilek JE. Evaluation of temephos and chlorpyrifos-methyl against Culex pipiens L. (Diptera: Culicidae) larvae in septic tanks in Antalya, Turkey. J Med Entomol , 2006a ; 43: 1195-1199

Cetin H, Yanikoglu A, Cilek JE. Efficacy of diflubenzuron, a chitin synthesis inhibitor, against Culex pipiens larvae in septic tank water. J Am Mosquito Contr, 2006b ; 22: 343-345.

Chaudhary A, Sharma P, Nadda G, Tewary DK, Singh B. Chemical composition and larvicidal activities of the Himalayan cedar, Cedrus deodara essential oil and its fractions against the diamondback moth, Plutella xylostella. Journal of Insect Science, 2011; 11:157.

Cheddadi R, Fady B, François L, Hajar L, Suc JP, Huang K, Demateau M, Vendramin G, Ortu E. Putative glacial refugia of $C$. atlantica deduced from quaternary pollen records and modern genetic diversity. Journal of Biogeography, 2009; 36: 1361-1371.

Copping LG. Crop protection agents from nature. The Royal Society of Chemistry, 1996.

Cui F, Lin LF, Qiao CL, Xu Y, Marquine M, Weill M, Raymond M. Insecticide resistance in Chinese populations of the Culex pipiens complex through esterase overproduction. Ent Exp Appl, 2006; 120:211-220.

El Ouali Lalami A, El-Akhal F, El Amri N, Maniar S, Faraj C. State resistance of the mosquito Culex pipiens towards temephos central Morocco. Bull Soc Pathol Exot, 2014; 107:194-198.

El Ouali Lalami A, EL-Akhal F, Maniar S, Ez zoubi Y, Taghzouti K. Chemical Constituents and Larvicidal Activity of Essential Oil of Lavandula stoechas (Lamiaceae) From Morocco Against the Malaria Vector Anopheles Labranchiae (Diptera: Culicidae). Int J Pharmacognosy and Phytochem Res, 2016; 8(3):505-511.

El Ouali Lalami A, El-Akhal F, Ez Zoubi Y, Taghzouti K. Study of Phytochemical Screening and Larvicidal Efficacy of Ehtanolic Extract of Salvia officinalis (Lamiaceae) from North Center of Morocco against Culex pipiens (Diptera: Culicidae) Vector of Serious Human Diseases. Int J Pharmacognosy and Phytochem Res, 2016; 8(10):1663-1668.

El-Akhal F, Maniar S, El Bachir A, Chafiqa F, Badoc A, El Ouali Lalami A. Resistance of Culex pipiens (Diptera: Culicidae) to Organophosphate Insecticides in Central Morocco. International Journal of Toxicological and Pharmacological Research, 2016; 8(4):263-268

El-Akhal F, EL Ouali lalami A, EZ Zoubi Y, Greche H, Guemmouh R. Chemical composition and larvicidal activity of Culex pipiens (Diptera: Culicidae) of essential oil of Origanum majorana (Lamiaceae) cultivated in Morocco. Asian Pac J Trop Biomed, 2014; 4(1):930-935.

EL-Akhal F, Guemmouh R, Greche H, El Ouali Lalami A. Valorization as a bio-insecticide of essential oils of Citrus sinensis and Citrus aurantium cultivated in center of Morocco. J Mater Environ Sci., 2014; 5 (S1):2319-2324

Faraj C, El Kohli M, El Rhazi M, Laqraa M, Lyagoubi M. Niveau actuel de la résistance du moustique Culex pipiens aux insecticides au Maroc. Sc Lett., 2002; 4:4.

Farjon A. A Natural History of Conifers. Timber Press, Portland, 2008:304.

Huseyin C, Yusuf K, Kani I, and Atila Y. Larvicidal effect of Cedrus libani seed oils on mosquito Culex pipiens. Pharmaceutical Biology, 2009; 47(8):665-668

Linares JC, Taïqui L, Camarero JJ. Increasing drought sensitivity and decline of Atlas cedar (C. atlantica) in the Moroccan Middle Atlas forests. Forests, 2011; 2:777-796.
M'hirit $\mathrm{O}$, Samih A and Malagnoux M. Le cèdre de l'Atlas ( $C$. atlantica Manetti). Présentation générale et état des connaissances à travers le Réseau Méditerranéa «le cèdre». Ann Rech For Maroc, 1993; 27 (spécial):1361.

Mansouri N, Strani B, Ghanmi M, El ghadraoui L, Aafi A, and Farah A. Valorisation des huiles essentielles de Juniperus thurifera et Juniperus oxycedrus du Maroc. Phytothérapie, 2010; 8:166-170.

Marcum DB \& Hanson BR. Effect of irrigation and harvest timing on peppermint oil yield in California. Agricultural Water Management, 2006; $82: 118-128$.

Mathieu P, Anne-Marie N, Vincent C, Joseph C, and Ange B. Chemical Variability of the Wood Essential Oil of $C$. atlantica Manetti from Corsica. Chemistry \& Biodiversity, 2011; 8:344-351.

Monica RL, Saab A, Tundis R, Giancarlo A, Lampronti I, Menichini F, Gambari R, Cinatl J and Wilhelm Doerr H. Phytochemical analysis and in vitro evaluation of the biological activity against herpes simplex virus type 1 (HSV-1) of Cedrus libani. A Rich Phytomed, 2008; 15:79-83

Muñoz BJ, Arrillaga I \& Segura J. Essential oil variation within and among natural populations of Lavandula latifolia and its relation to their ecological areas. Biochemical Systematics and Ecology, 2007; 35:479-488.

Naples JM, Shiff CJ, RosIer KH. Schistosoma mansoni: Cercaricidal effects of cedar wood oil and various of its components. Am J Trop Med Hyg, 1992; 95:390-396.

Necmettin Y, Alma MH, Nitz S, Hubert K and Tuncay F. Chemical Composition of the Essential Oils from Oleores in on Cones of Cedrus libani. Asian J Chem, 2005; 17:25-30.

Rachid R, Badr S, Touria Z, Mohamed G, Abderrahman A, Mohamed EO and Amar B. Chemical composition, antibacterial and antifungal activities of the $C$. atlantica (Endl) Manetti ex Carrier seeds essential oil. Mediterranean Journal of Chemistry, 2014; 3(5): 1034-1043.

Rhafouri R, Strani B, Zair T, Ghanmi M, Aafi A, El Omari M and Bentayeb A. Chemical composition, antibacterial and antifungal activities of the $C$. atlantica (Endl.) Manetti ex Carrier seeds essential oil. Mediterranean Journal of Chemistry, 2014; 3(5):1027-1036.

Samuel T, Arul Samraj D, Jeyasundar D and Keduokhrienuo C. Larvicidal Efficacy of Plant Oils Against the Dengue Vector Aedes aegypti (L.) (Diptera: Culicidae. Middle-East Journal of Scientific Research, 2013; 13 (1) 64-68.

Singh D and Agarwal SK. Himachalol and beta-himachalene: Insecticidal principles of Himalayan Cedar wood oil. J Chem Ecol, 1988; $14: 1145-1151$

Sugita K, Ouchi J, Okajima T and Watanabe H. Topical NonSteroidal Anti- Inflammatory Agents Containing Essential Oils and BodyWarming Substances. Jpn. Kokai Tokyo, 2004; JP 2004175723 A2 20040624.

Teisseire P and Plattier M. New bicyclic sesquiterpenoid ketone isolated from the essential oil of the Atlas cedar. Recherches, 1974; 19:167172.

WHO. Guide to the field determination of major groups of pathogens affecting arthropod vectors of human diseases. Document/WHO/VBC., 1982; 82: 860.

Whitley RJ, Kimberlin DW and Roizman B. Herpes simplex viruses. Clin Infect Dis, 1998; 26:97-109.

Zrira S and Ghanmi M. Chemical Composition and Antibacterial Activity of the Essential of $C$. atlantica (Cedar wood oil). Journal of Essential Oil Bearing Plants, 2016; 19 (5):1267 - 1272.

\section{How to cite this article:}

EZ Zoubi Y, El-Akhal F, Farah A, Taghzouti K, El Ouali Lalami A. Chemical composition and larvicidal activity of Moroccan Atlas Cedar (Cedrus atlantica Manetti) against Culex pipiens (Diptera: Culicidae). J App Pharm Sci, 2017; 7 (07): 030-034. 